\title{
Social-class differences in Poland pronounced in stature, but absent in gene frequencies
}

\author{
Lidia Gronkiewicz \\ Institute of Anthropology, Polish Academy of Sciences, Kuźnicza 35, \\ 50-951 Wrocław, Poland
}

\begin{abstract}
The marked social-class differences in physical growth of youth, as well as in a variety of health-related biological characteristics of adults, observed in many industrial societies are as a rule interpreted as nongenetic in nature and therefore as purely phenotypic manifestations of social inequalities in living standards. However, this tacitly adopted "no genetics" assumption has very seldom been subject to any empirical validation. The present study is an attempt to provide such validation for the population of Poland. The material was collected over the period from 1960 to 1990 and drawn from cases of disputed paternity. It comprises a total of 8861 adults of both sexes; roughly half of them are males, the presumptive fathers. It was found that throughout the period of several decades covered by this study no significant differences appeared between the various social strata in allele frequencies of any of the following 8 genetic loci: ABO, MN, Rh(D), Hp, Gm(a), AcP, PGM1, EsD. Nor is there any suggestion of long-term trends in allele frequencies for any of the above loci. This pattern is in sharp contrast to the strikingly regular social gradients, and intense secular trends, observed in the population of post-war Poland in stature and age at menarche. It is postulated that the above findings are consonant with the "no genetic component" hypothesis.
\end{abstract}

KEY WORDS social stratification, allele frequencies, secular trends

Prz. Antropol. - Anthropol. Rev. (2001), vol. 64, pp. 73-79, Fig. 1, Tables 4. ISBN 8386969-64-4, ISSN 0033-2003

The present report is an attempt to answer the question whether any significant differences in genetic make-up exist between different social classes in the present-day population of Poland. The problem is of essential importance for the proper interpretation of the strikingly regular social gradients observed in post-war Poland in various metric features of children and adults, such as height-for-age, age at menarche, fatness, age-related degree of demineralisation of bones, longevity, etc. [BIELICKI 1986; BIELICKI and SZKLARSKA 1999; HULANICKA et al. 1994, 1999; ROGUCKA and BIELICKI 1999; ROGUCKA et al. 1998; WELON et al. 1999]. Such gradients have consistently been 
interpreted as reflecting solely the social inequalities in living standards, i.e., the tacit assumption was made that no significant differences exist between the various social strata in Poland in their genetic composition, especially in genes affecting the above features. The above assumption, however, has never been tested. This report is a first step towards providing such an indirect test on the basis of gene frequencies in traits having a known mode of inheritance.

\section{Materials and methods}

The material has been collected in the Department of Anthropology, Polish Academy of Sciences, in the course of disputed paternity tests conducted in the years 1960-1990. The sample includes 4513 adult males and 4348 adult females from all social strata and all regions of Poland. For the present analysis the following information on each subject were used: 1 . year of birth; 2 . age at examination; 3. stature $(\mathrm{cm}) ; 4$. phenotype in each of the following eight serological traits (the only ones consistently recorded throughout the three decades considered and thus available for the purpose of this study): ABO, MN, Rh(D), Hp, Gm(a), AcP, PGM1, EsD; and 5. paternal education and occupation. All subjects were aged 25-45 years at the time of examination. Allele frequencies were for each locus calculated from phenotype frequencies by standard methods.

Differences in stature, and in allele frequencies for the above eight serological traits, were analyzed both between generations (birth cohorts) and, within cohorts, between groups of subjects equated for paternal social status. Four birth cohorts and four social groups were distinguished. Cohorts: 1. 19051939; 2. 1940-1949; 3. 1950-1959; 4. 1960-1972. Social groups (according to father's occupational status): A - nonmanual worker; B - skilled manual worker; C - semi-skilled or unskilled manual worker; D - peasant, with no more than grade-school education. All four birth cohorts were considered for the inter-generation comparisons, but between-social group comparisons were made within two cohorts only, the 19401949 and the 1950-1959 cohort, because the other two contained insufficient amounts of social variation. The earliest cohort had insufficient number of nonmanual workers (group A) among females, while the latest one insufficient numbers of unskilled workers and of peasants (groups $\mathrm{C}$ and $\mathrm{D}$ ) among the males. The significance of statural differences was estimated by means of the Student's t-test for independent samples, that of differences in allele frequencies by the $\chi^{2}$ test [RACE and SANGER 1962].

The analysis of gene frequencies in the $\mathrm{Rh}$ system was limited to phenotypes $\mathrm{Rh}(\mathrm{D}+)$ and $\mathrm{Rh}(\mathrm{D}-)$; thus, the system was treated as a two-allelic locus, with the $\mathrm{Rh}(+)$ allele opposed to all others.

\section{Findings}

As can be seen in Table 1, and in full accordance with many earlier studies of the population of Poland (e.g., BIELICKI and SZKLARSKA [1999]), a clear secular trend towards taller stature appears both among males and females. Among males the trend is present within each of the four social groups considered. Among females such shifts can be seen among daughters of peasants (group D) and of unskilled workers (group C) (Table 2). 
Table 1. Mean stature of males and females by birth cohort (all subjects $25-45$ years old at time of examination)

\begin{tabular}{|c|c|c|c|c|c|c|c|c|}
\hline \multirow[b]{3}{*}{ Stature } & \multicolumn{4}{|c|}{ Males } & \multicolumn{4}{|c|}{ Females } \\
\hline & \multicolumn{4}{|c|}{ Birth cohort } & \multicolumn{4}{|c|}{ Birth cohort } \\
\hline & $\begin{array}{c}1 \\
1905-39\end{array}$ & $\begin{array}{c}2 \\
1940-49\end{array}$ & $\begin{array}{c}3 \\
1950-59 \\
\end{array}$ & $\begin{array}{c}4 \\
1960-70 \\
\end{array}$ & $\begin{array}{c}1 \\
1905-39 \\
\end{array}$ & $\begin{array}{c}2 \\
1940-49\end{array}$ & $\begin{array}{c}3 \\
1950-59 \\
\end{array}$ & $\begin{array}{c}4 \\
1960-70 \\
\end{array}$ \\
\hline $\bar{X}$ & 169.41 & 172.06 & 173.36 & 174.42 & 155.98 & 158.70 & 159.41 & 159.60 \\
\hline SD & 5.95 & 6.05 & 6.24 & 6.16 & 6.05 & 6.26 & 6.08 & 6.30 \\
\hline $\mathrm{N}$ & 847 & 1148 & 1386 & 206 & 583 & 881 & 1243 & 232 \\
\hline
\end{tabular}

In males: difference significant at $\mathrm{p}<0.05$ between cohorts 3-4; differences significant at $\mathrm{p}<0.001$ between cohorts $1-2$ and 2-3.

In females: difference significant at $\mathrm{p}<0.01$ between cohorts 2-3; difference significant at $\mathrm{p}<0.001$ between cohorts 1-2.

In addition, and in perfect accordance with many other Polish studies, a clear social gradient emerges in this material in the statural data: both in males and females mean statures increase monotonically with the subject's increasing position on the social scale (Table 2). The differences in stature between the social strata are, within each gender, significant between groups $\mathrm{A}$ and $\mathrm{B}$, and between $\mathrm{B}$ and $\mathrm{C}+\mathrm{D}$, and this holds both for the 1940-1949 and for the 19501959 birth cohort.

A contrastingly different picture emerges from the data on allele frequencies in the 8 serological loci. First, out of the total number of 16 independent between-cohort (8 loci x 2 genders) shown in Table 3 in only two instances does a significant difference between cohorts appear: in the Hp gene in males between cohorts 2 and 4, and in the Rh gene in females between cohorts 2 and 3 . Both these deviations from intergenerational stability are clearly accidental fluctuations: none of the 16 independent time-series presented in Table 3 shows any consistent tendency for an allele frequency to rise or to fall with time. There is thus no suggestion of any secular trend in any of the eight genetic loci available for study. Second, and more importantly in the context of this report, no significant differences in allele frequencies appear between the four social groups distinguished, nor is there any suggestion of any regular, gradientlike variation in these frequencies along the social scale (Table 4, Fig. 1). This is true for every one of the 8 loci, for each gender, and for each of the two birth cohorts considered.

Table 2. Stature (cm) of subjects by social background (groups A,B,C,D) ${ }^{1}$, and year of birth (two decades) $)^{2}$; all subjects aged $25-45$ years

\begin{tabular}{|c|c|c|c|c|c|c|c|c|c|}
\hline \multirow[b]{3}{*}{ Birth cohorts } & & \multicolumn{4}{|c|}{ Males } & \multicolumn{4}{|c|}{ Females } \\
\hline & & \multicolumn{4}{|c|}{ Social groups } & \multicolumn{4}{|c|}{ Social groups } \\
\hline & & $\mathrm{A}$ & $\mathrm{B}$ & $\mathrm{C}$ & $\mathrm{D}$ & $\mathrm{A}$ & $\mathrm{B}$ & $\mathrm{C}$ & $\mathrm{D}$ \\
\hline Born in years & $\bar{X}$ & 173.84 & 172.49 & 171.93 & 171.11 & 161.02 & 159.68 & 157.90 & 157.53 \\
\hline \multirow[t]{2}{*}{$1940-1949$} & $\mathrm{SD}$ & 6.33 & 6.18 & 5.35 & 5.90 & 6.63 & 6.23 & 6.58 & 5.70 \\
\hline & $\mathrm{N}$ & 168 & 366 & 157 & 457 & 92 & 302 & 158 & 329 \\
\hline Born in years & $\bar{X}$ & 174.81 & 173.85 & 172.82 & 172.38 & 160.85 & 159.60 & 158.91 & 158.88 \\
\hline \multirow[t]{2}{*}{ 1950-1959 } & $\mathrm{SD}$ & 6.57 & 6.12 & 5.95 & 6.18 & 5.88 & 6.12 & 6.15 & 5.97 \\
\hline & $\mathrm{N}$ & 187 & 562 & 167 & 470 & 126 & 554 & 207 & 356 \\
\hline
\end{tabular}

${ }^{1}$ social groups A,B,C,D defined in text.

${ }^{2}$ for significance of between-social group and between-cohort differences see text. 
Table 3. Frequencies of selected alleles in 8 serological loci, and sample size $(\mathrm{N})$ among males and females from four successive birth cohorts

\begin{tabular}{|c|c|c|c|c|c|c|c|c|c|}
\hline \multirow[b]{3}{*}{ Locus } & \multirow[b]{3}{*}{ Allele } & \multicolumn{4}{|c|}{ Males } & \multicolumn{4}{|c|}{ Females } \\
\hline & & \multicolumn{4}{|c|}{ Birth cohort } & \multicolumn{4}{|c|}{ Birth cohort } \\
\hline & & $\begin{array}{c}1 \\
1905-39 \\
\end{array}$ & $\begin{array}{c}2 \\
1940-49 \\
\end{array}$ & $\begin{array}{c}3 \\
1950-59 \\
\end{array}$ & $\begin{array}{c}4 \\
1960-72 \\
\end{array}$ & $\begin{array}{c}1 \\
1905-39 \\
\end{array}$ & $\begin{array}{c}2 \\
1940-49 \\
\end{array}$ & $\begin{array}{c}3 \\
1950-59 \\
\end{array}$ & $\begin{array}{c}4 \\
1960-72 \\
\end{array}$ \\
\hline \multirow[t]{3}{*}{$\mathrm{ABO}$} & $\mathrm{A}$ & 0.269 & 0.273 & 0.276 & 0.266 & 0.291 & 0.281 & 0.287 & 0.294 \\
\hline & $\mathrm{O}$ & 0.572 & 0.564 & 0.574 & 0.564 & 0.552 & 0.555 & 0.552 & 0.555 \\
\hline & $(\mathrm{N})$ & 1272 & 1265 & 1610 & 364 & 653 & 1080 & 1864 & 751 \\
\hline \multirow[t]{2}{*}{$\mathrm{MN}$} & $\mathrm{M}$ & 0.579 & 0.586 & 0.598 & 0.565 & 0.593 & 0.579 & 0.584 & 0.607 \\
\hline & $(\mathrm{N})$ & 1272 & 1265 & 1584 & 364 & 650 & 1075 & 1864 & 751 \\
\hline \multirow[t]{2}{*}{$\mathrm{Rh} *$} & $\mathrm{D}+$ & 0.565 & 0.573 & 0.579 & 0.577 & 0.560 & 0.541 & 0.584 & 0.552 \\
\hline & $(\mathrm{N})$ & 1262 & 1266 & 1611 & 364 & 647 & 1075 & 1864 & 751 \\
\hline \multirow[t]{2}{*}{$\mathrm{Hp} *$} & $\mathrm{Hp}^{1}$ & 0.368 & 0.388 & 0.360 & 0.344 & 0.373 & 0.378 & 0.377 & 0.389 \\
\hline & $(\mathrm{N})$ & 948 & 1200 & 1603 & 363 & 407 & 977 & 1842 & 751 \\
\hline \multirow[t]{2}{*}{$\mathrm{Gm}(\mathrm{a})$} & $\mathrm{Gm}^{1}$ & 0.216 & 0.213 & 0.217 & 0.224 & 0.210 & 0.224 & 0.191 & 0.208 \\
\hline & $(\mathrm{N})$ & 736 & 1091 & 1590 & 364 & 274 & 833 & 1802 & 747 \\
\hline \multirow[t]{3}{*}{$\mathrm{AcP}$} & $\mathrm{P}^{\mathrm{a}}$ & 0.357 & 0.350 & 0.348 & 0.335 & & 0.391 & 0.340 & 0.354 \\
\hline & $\mathrm{P}^{\mathrm{c}}$ & 0.104 & 0.090 & 0.086 & 0.095 & & 0.070 & 0.082 & 0.077 \\
\hline & $(\mathrm{N})$ & 297 & 590 & 1439 & 363 & & 331 & 1454 & 749 \\
\hline \multirow[t]{2}{*}{ PGM1 } & $\mathrm{PGM}^{1}$ & 0.727 & 0.753 & 0.740 & 0.764 & & 0.714 & 0.745 & 0.742 \\
\hline & $(\mathrm{N})$ & 211 & 428 & 1095 & 346 & & 238 & 1054 & 689 \\
\hline \multirow[t]{2}{*}{ EsD } & $\mathrm{EsD}^{1}$ & 0.901 & 0.889 & 0.891 & 0.913 & & 0.940 & 0.902 & 0.907 \\
\hline & $(\mathrm{N})$ & 167 & 347 & 990 & 355 & & 184 & 897 & 713 \\
\hline
\end{tabular}

* differences between only two birth cohorts significant at $\mathrm{p}<0.05$ (for explanation see text).

Table 4. Frequencies of selected alleles in 8 serological loci, and sample size $(\mathrm{N})$ in groups of subjects differing in social background (groups A,B,C,D) ${ }^{1}$ from the 1940-1959 birth cohort $^{2}$

\begin{tabular}{|c|c|c|c|c|c|c|c|c|c|}
\hline \multirow[b]{3}{*}{ Locus } & \multirow[b]{3}{*}{ Allele } & \multicolumn{4}{|c|}{ Males } & \multicolumn{4}{|c|}{ Females } \\
\hline & & \multicolumn{4}{|c|}{ Social groups } & \multicolumn{4}{|c|}{ Social groups } \\
\hline & & A & $\mathrm{B}$ & $\mathrm{C}$ & $\mathrm{D}$ & $\mathrm{A}$ & $\mathrm{B}$ & $\mathrm{C}$ & $\mathrm{D}$ \\
\hline \multirow[t]{3}{*}{$\mathrm{ABO}$} & A & 0.299 & 0.265 & 0.273 & 0.277 & 0.274 & 0.272 & 0.272 & 0.293 \\
\hline & $\mathrm{O}$ & 0.541 & 0.580 & 0.574 & 0.567 & 0.561 & 0.562 & 0.562 & 0.539 \\
\hline & $(\mathrm{N})$ & 393 & 1056 & 361 & 1066 & 262 & 1202 & 520 & 959 \\
\hline \multirow[t]{2}{*}{$\mathrm{MN}$} & $\mathrm{M}$ & 0.602 & 0.592 & 0.580 & 0.579 & 0.580 & 0.570 & 0.588 & 0.595 \\
\hline & $(\mathrm{N})$ & 393 & 1056 & 361 & 1066 & 262 & 1202 & 520 & 959 \\
\hline \multirow[t]{2}{*}{$\mathrm{Rh}$} & $\mathrm{D}+$ & 0.563 & 0.564 & 0.616 & 0.581 & 0.609 & 0.550 & 0.579 & 0.574 \\
\hline & $(\mathrm{N})$ & 393 & 1056 & 361 & 1066 & 262 & 1202 & 520 & 959 \\
\hline \multirow[t]{2}{*}{ Hp } & $\mathrm{Hp}^{1}$ & 0.399 & 0.364 & 0.367 & 0.372 & 0.405 & 0.377 & 0.358 & 0.380 \\
\hline & $(\mathrm{N})$ & 386 & 1038 & 346 & 1033 & 254 & 1157 & 493 & 915 \\
\hline \multirow[t]{2}{*}{ Gm(a) } & $\mathrm{Gm}^{1}$ & 0.206 & 0.211 & 0.209 & 0.219 & 0.207 & 0.201 & 0.190 & 0.206 \\
\hline & $(\mathrm{N})$ & 3373 & 1003 & 318 & 987 & 242 & 1094 & 459 & 840 \\
\hline \multirow[t]{3}{*}{$\mathrm{AcP}$} & $\mathrm{P}^{\mathrm{a}}$ & 0.355 & 0.353 & 0.361 & 0.337 & 0.343 & 0.364 & 0.313 & 0.336 \\
\hline & $\mathrm{P}^{\mathrm{c}}$ & 0.098 & 0.083 & 0.072 & 0.093 & 0.091 & 0.076 & 0.092 & 0.073 \\
\hline & $(\mathrm{N})$ & 290 & 798 & 244 & 697 & 181 & 789 & 292 & 523 \\
\hline \multirow[t]{2}{*}{ PGM1 } & $\mathrm{PGM}^{1}$ & 0.721 & 0.743 & 0.770 & 0.745 & 0.750 & 0.730 & 0.733 & 0.756 \\
\hline & $(\mathrm{N})$ & 222 & 604 & 183 & 514 & 140 & 586 & 210 & 356 \\
\hline \multirow[t]{2}{*}{ EsD } & $\mathrm{EsD}^{1}$ & 0.890 & 0.897 & 0.890 & 0.883 & 0.937 & 0.904 & 0.906 & 0.905 \\
\hline & $(\mathrm{N})$ & 191 & 536 & 169 & 441 & 119 & 491 & 186 & 285 \\
\hline
\end{tabular}

${ }^{1}$ social groups $\mathrm{A}, \mathrm{B}, \mathrm{C}, \mathrm{D}$ defined in text.

2 all differences are non-significant by chi-square. 


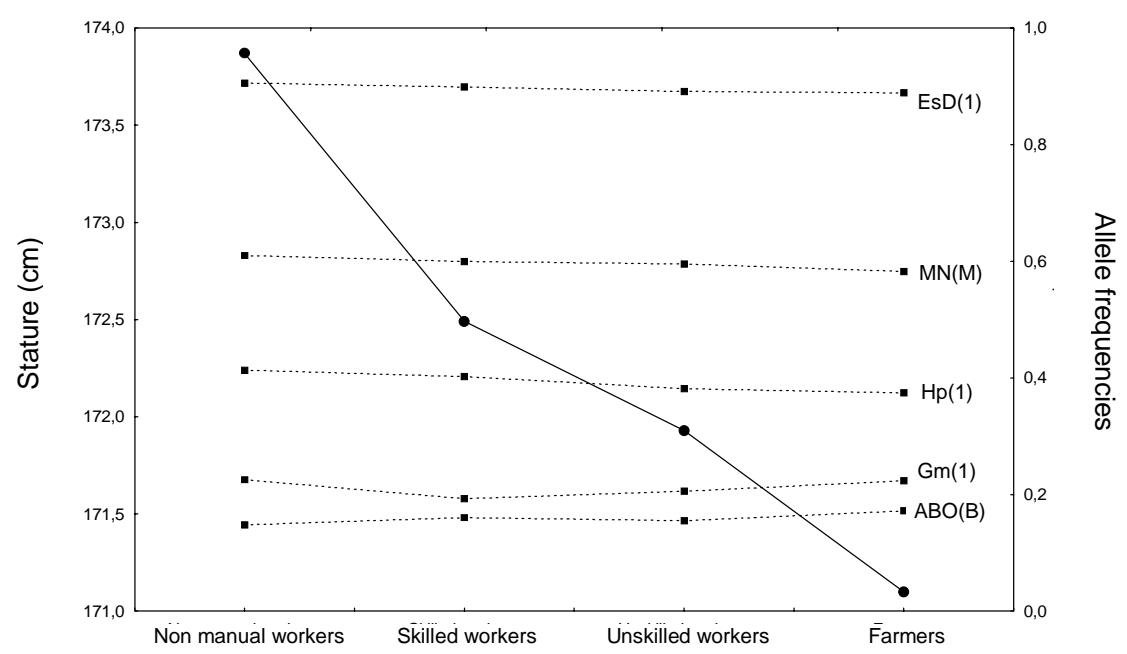

Fig. 1. Mean statures (solid line) and allele frequencies for five selected genetic loci (dotted lines) in four social classes of Polish adult males from the 1940-49 birth cohort.

\section{Discussion and conclusions}

Obviously, subjects drawn from cases of disputed paternity can not be considered a random sample of the national population as a whole. In a material of such derivation groups lower on the social scale tend to be over-represented. This bias, however, is of no relevance from the viewpoint of the present analysis, as long as the various social groups considered are each represented by numbers of individuals sufficient to yield statistically reliable mean statures and allele frequencies. In this context, it is worthy of noting that the gene frequencies here reported prove quite similar to those found earlier by SZCZOTKA and SCHLESINGER [1980] for a large random sample of the population of Poland. It should also be noted that the social group-specific mean statures in the present material are consistent with those reported in studies of other Polish samples (e.g., BIELICKI et al.
[1992]; ROGUCKA and WELON [1996]).

The results of this study show that - in sharp contrast to the picture emerging from analyses of mean statures - allele frequencies in each of the genetic markers available for analysis in this material show no indication either (a) of any inter-generation shifts or (b) of any regular social variation, in either gender and within either birth cohort. The above result accords with the hypothesis that in the population of Poland there have existed during the post-war decades no social-class differences in genetic composition. This is consistent with the assumption that the marked betweensocial group and between-generation differences in physical growth observed in post-war Poland can indeed be regarded as "free from genetics", i.e., that it is indeed legitimate to interpret such differences as very probably brought about solely by social inequalities (and of historical changes) in living conditions. 
Needless to say, the inference: "if no differences appear between two social groups in allele frequencies for monogenic traits then presumably no differences exists between these groups as well in allele frequencies affecting stature" - is based on a per analogiam type of reasoning and thus may be taken as evidence of a suggestive rather than direct nature. Theoretically, the possibility could not be excluded that in the population of Poland the higher social strata, although they fail to differ from the lower strata in any of the genetic loci available for study, do differ, for some reason, from the lower ones in having greater frequencies of genes predisposing to tallness. Such a supposition, however, would lack any independent evidence and would seem very much taken from the air and unlikely. Also, there is a reason to think that even if taller individuals were more likely than shorter ones to climb the social scale - such differential upward social mobility would probably fail to have genetic consequences, i.e., to change the distribution of genes for tallness along the social scale [BIELICKI and SZKLARSKA 1999]. In sum, the present findings are fully consonant with the assumption that the different social strata in Poland constitute, genetically, random samples drawn from the sample gene pool of a single Mendelian population. Moreover, as pointed out earlier [BIELICKI and WELON 1982; BIELICKI 1986], the absence of genetic differences between social classes in their overall genetic makeup is exactly what one would intuitively expect from certain peculiarities of Poland's demographic and social history during the post-World War II decades.

\section{References}

BIELICKI T., 1986, Growth as a measure of economic well-being of populations, the twentieth century, [in:] Human Growth, a Comprehensive Treatise, F. Falkner \& J.M. Tanner (eds.), New York: Plenum Press, 3, 282-305

BielicKi T., A. SZKLARSKA, 1999, Secular trends in stature in Poland: national and social group-specific, Ann. Hum. Biol., 26, 251-258

BIELICKI T., Z. WELON, 1982, Growth data indicators of social inequalities: the case of Poland, Yearbook Phys. Anthropol., 25, 153167

Bielicki T., R.M. Malina, A. Waliszko, 1992, Monitoring the dynamics of social stratification: statural variation among Polish conscripts in 1976 and 1986, Am. J. Hum. Biol., 4, 345-352

Hulanicka B., L. Gronkiewicz, A. Waliszko, 1999, Stature of boys post Warld War II migrants, Ann. Hum. Biol., 6, 549-559

Hulanicka B., E. Kolasa, A. WaliszKo, 1994, Dziewczęta z Górnego Slaska, Monografie Zakładu Antropologii PAN, 11

RACE R.R., R. SANGER, 1962, Blood Groups in Man, 4th Edition, Oxford: Blackwell Scientific Publications

RogUCKa E., T. BIELICKI, 1999, Social contrasts in the incidence of obesity among adult largecity dwellers in Poland, J. Biosoc. Sci., 31, 419-423

RogucKa E., Z. Welon, 1996, Fitness of professionals and skilled workers in Poland, J. Biosoc. Sci., 28, 161-176

RogucKa E., Z. Welon, T. Bielicki, 1998, Społeczne kontrasty $w$ stopniu mineralizacji obwodowego kośćca u mężczyzn, mieszkańców Wroctawia, [in:] Spoleczne kontrasty $w$ stanie zdrowia Polaków, AWF, Warszawa, pp. $35-40$

SzCZOTKA H., D. Schlesinger, 1980, Tablice do obliczania prawdopodobieństwa ojcostwa w populacji polskiej, Materiały i Prace Antropologiczne, 98, 3-52

Welon Z., T. BIELICKI, E. RogucKa, R.M. MALINA, 1999, Effect of education and marital status on premature mortality among urban adults in Poland, 1988-1989, Am. J. Hum. Biol., 11, 397-403 


\section{Streszczenie}

Obserwowane w wielu uprzemysłowionych krajach istniejące różnice społeczne w rozwoju fizycznym młodzieży jak i w różnych biologicznych cechach osób dorosłych, są traktowane jako niegenetyczne w swojej naturze i wobec tego są czystym fenotypowym odzwierciedleniem niejednakowych warunków życia różnych grup społecznych. Jednakże to założenie braku komponenty genetycznej ma bardzo rzadko empiryczne uzasadnienie. Celem tej pracy jest zbadanie zasadności tego stwierdzenia dla populacji polskiej. Materiał pochodzi z archiwum Pracowni Dochodzenia Ojcostwa z Wrocławia z lat 1960 i 1990, i zawiera dane o 8861 dorosłych mężczyznach i kobietach. W analizowanym materiale nie stwierdzono istotnych różnic społecznych i międzypokoleniowych trendów w częstościach alleli w żadnym z 8 badanych loci: ABO, MN, Rh(D), Hp, Gm(a), AcP, PGM1, EsD. Tak więc bardzo wyrazistym i regularnym gradientom społecznym w cechach rozwoju fizycznego towarzyszy w Polsce brak gradientów społecznych w prostych markerach genetycznych. 